\title{
Octylchlororesorcinol の合成過程中に生成
}

\section{されろ驅虫効果增强物質の本態について}

\author{
山崎英正 万波忠三郎 高 岡 健 男
}

（岡山大學醫學部藥理學敎室〔山崎教授〕）

（昭和二十七年九月一日受付）

さきに 4-n-Octyl-6-chlororesorcinol (O. C. R.) がその合成ロットによつて駱虫効果に著しい㜀違のある ことを見出したわれわれ (山崎, 万波，前田)1)はその原因の手が〉り得よらとして，効果の相違するいくつか の結晶について，三，三物理化學的性貿及び生物學的性賀を比較檢䒺した結果，効果の優れた結晶は純品結晶に比

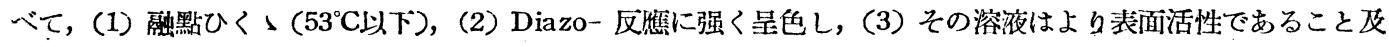
び（4）殺蜔虫力强く（5）輕度ながら瑇性及び局所刺战性が大であること等を主要な相違點として認めた.

この强效力結晶の示した純品結晶と相違する性貿は，含有される不純物貿に由來するものであることはいらま であないが，上述の物理化學的性資は 4-n-Octylresorcinol (O. R.)をこの不純物になぞらえる場合に一燋の說 明がりく事も判明したのである.

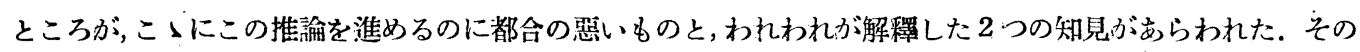
1つはX-線粉末䉣傎分析の結果, 作用の强い不純 O.C. R. は純 O.C.R.結晶と迴折格子面間隔か殆ど一致L, 後者のそれとは明らかに區別出來る O. R.に特有の迴折像をその中に見出だすことができないとい5，この檢 查を依賴した宇野助敉授 (京大藥學科) の所見) であつて，前者中に O.R. が結晶狀に混入するといらことは この場合考えにくいといらことであつた. 今 1つは當時豫備的に試みられた少數例の臨床䐝驗に於て O. C. R. に O.R.の10 30\%までを加えた配合物では既知の强効力 O. C. R. でえられていた効果ほどの强力な作用が 認められなかつだ2ことであつた。

そこで，われわれ〔山崎，万波 ${ }^{3}$ 〕はこの問題に關する追究の方法を一變し，富田教授 (京大藥學科) 上尾教 授 (阪大藥學科)，日本油脂呼究所高橋氏らの合成上の協力を願つて，有效結晶の生成とその合成條件特に原料 及び蒸溜條件との關係を檢討することにした。この呼究で14 種の生成物に就て檢索が行われたが, 試みられた範 圍の合成條件では何れも効果增强をきたすよ5な，或はそれだけの量の成分を混入する餘地を與えることができ なからた。

ところが，その後ひきつがいて合成法に就ての砄究が富田敎堂で行われ，小林，渡邊兩氏によつて KW-I 及

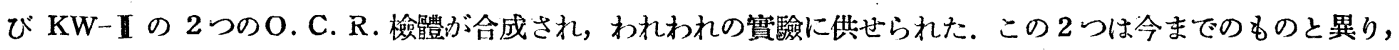
極めて顯著な䮥虫効果を示すことが制明したのである.この 2 檢體は蒸溜侍の減壓程度を少くし，溫度を高くし て蒸溜時生成物の分解を目諭んだものでありたが，得られた兩檢體ともDiazo-反應の呈色强く，表面活性大で あつて，初期の有效結晶と類似するところが多いことが制つた．叉Diazo一反篗呈色の吸光度は，これらの結晶 が O.C. R. 中に O.R. を20〜30\%含有すると假定した場合の程度にほよ゙一致した。

この知見の得られた時分，一方に於てわれわれはこの研究との關連性をも多少期待して；別に O. C. R.に O. R. を種々の比率に配合した混合物の性質についても系統的に檢討をすっめていた．その結果は前報2のよう に O.R.の一定範園の量比の配合によつて, かつて經驗した少數例の豫備的實驗の成績から豫想されたよりる

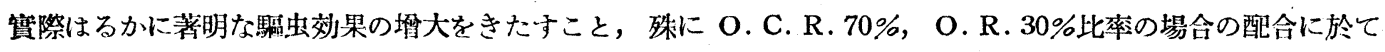
䮄虫効果に極めて著明な相乘現象のおきることを認めるにいたり，上述の知見と相俟つてこっに再び O.R.へ の關心が强く㬇起された．邓これと相前後して不純 O. C. R.のX-線备折像に關する問題を迫究中の宇野氏 により，O.C.R.に O.R.を一定量まで混融させた場合にも X-線粉末寫眞には O.R.の像が現われなくな 
るといら新知見がもたらされたのである。

かくてこの 2 つ事筫はこの不純物質を O.R. と省る推論に急速に途を拓いたわけで，こ扎いいで後述の 如く有効 O.C. R. のクロール含量が純品に比して少いことが制り，丈上尾敉授らががパーパークロマトグラフ によりて，これらの有效 O.C.R.が何れも，O．R．を含有することを確認するに及び，效果の强い O.C.R.

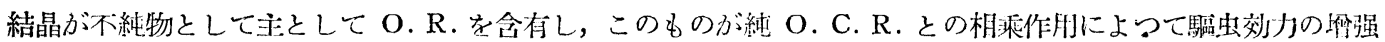
をなしていたものであることが漱く茲に闈明されるに至つたのである。そとてこの O.R. そのものは O.C.R.

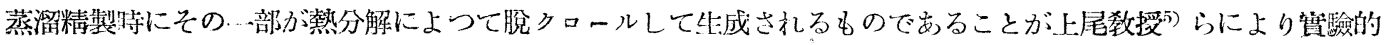
に登明された。

本砄究に關し，われわれの行つた前報告1) 以後の主萝な砄究队容は O.C.R.とO.R.の配合物の憸討と，

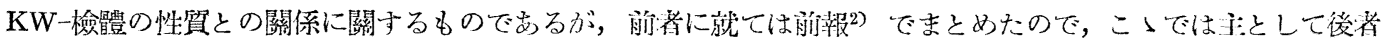
に就ての知見を中心に述べ，結論への道程を明らかにしておきたい。

\section{實驗材料及び方法}

KW-I 及び KW-II：純品 O. C. R. の純白に比べてかなり茶褐色色調をおびており，融點はいずれも約 43

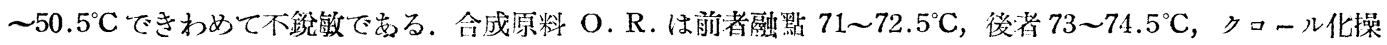

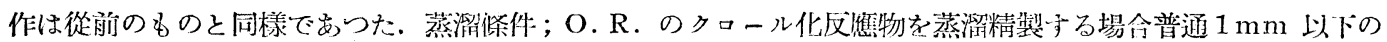

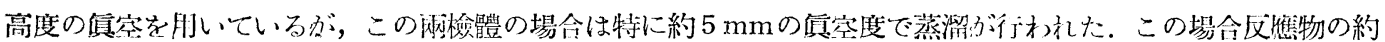

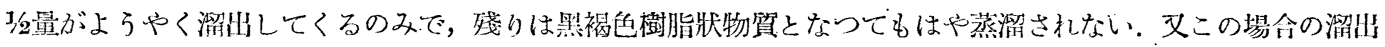

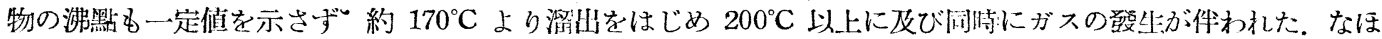
$1 \mathrm{~mm}$ 以下の屓空蒸溜特には沸默は㱠儿ど一定し且つ分解を伴わないで蒸溜されるのが常である。（小林，渡邊 兩氏による)

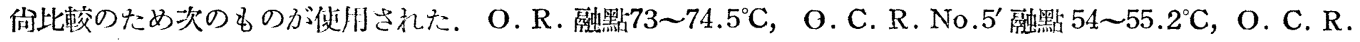

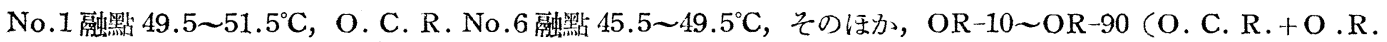

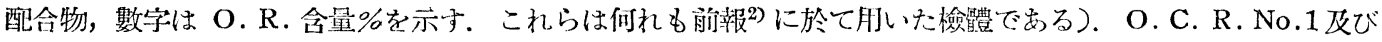

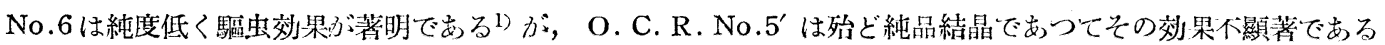
ことが判明している6).

實驗方法は既報27)と同樣である。

\section{實 驗 成 績}

\section{1. 豚蝈虫殺隇効力}

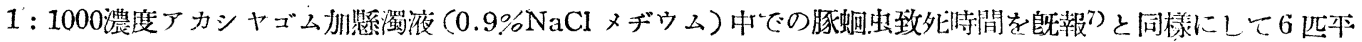

第 1 表. $\mathrm{KW}-\mathrm{I}$ 及び $\mathrm{Kw}-\mathbb{I I}$ U)豚蜔虫致死効果（濃度1: 1000).

\begin{tabular}{|c|c|c|}
\hline 檢 & $\begin{array}{l}\text { 機械的剌戟に對与る } \\
\text { 反磼停止時間(分)本均 }\end{array}$ & $\begin{array}{l}\text { 温熱剌戟 }\left(60^{\circ} \mathrm{C}\right) \text { に對する } \\
\text { 又痽停止時間(分) } \mathrm{M} \pm \mathrm{S} . \mathrm{E} .\end{array}$ \\
\hline $\mathrm{KW}-\mathbf{I}$ & 70 & $85 \pm 2.9$ \\
\hline KW - II & 68 & $83 \pm 2.3$ \\
\hline O.C. R. No. $5^{\prime}$ & 95 & $103 \pm 5.5$ \\
\hline O.R. & 75 & $95 \pm 2.6$ \\
\hline OR-20 & 73 & $87 \pm 3.1$ \\
\hline $\mathrm{OR}-30$ & 64 & $85 \pm 3.4$ \\
\hline O.C. R. No. 1 & 62 & $88 \pm 4.7$ \\
\hline O. C. R. No. 6 & 63 & $90 \pm 2.6$ \\
\hline
\end{tabular}

均でもとめだ結果は第 1 装の上万 でこの湮度に扮ける殺蜔虫性は 兩憸體とも高純度の O. C. R.

No. $5^{\prime} よ り$ 明以かに强?, 又 $\mathrm{O} . \mathrm{R}$. に比ベても優れ，打よそ OR-20 乃至 OR-30 と略及同程度と判斷 される.O.C.R.No.1，同 No. 6 に比べては心もち强い感じだが， その程度の差はこの實羷成綪のみ ふらは䗹定し難い。

2. 人體における蜔虫驅除効果

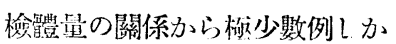

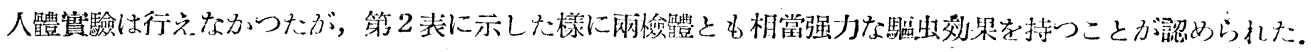


第2 表. KW- I 及び KW-II の䖲虫驅除效果.

\begin{tabular}{|c|c|c|c|c|c|c|c|c|}
\hline \multirow{2}{*}{ 檢 體 } & \multirow{2}{*}{ 例數 } & \multicolumn{5}{|c|}{ 卵 數 計 算 成 績 } & \multicolumn{2}{|c|}{ 排虫成 績 } \\
\hline & & $\begin{array}{l}\text { 前 E. P.G. } \\
\text { (個人本均) }\end{array}$ & $\begin{array}{l}\text { 後 E.P.G. } \\
\text { (個人伻均) }\end{array}$ & $\begin{array}{l}\text { 卯數減少菜 } \\
(\%) \text { (全體) }\end{array}$ & 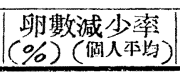 & 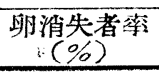 & $\begin{array}{c}\text { 排虫者索* } \\
(\%)\end{array}$ & 本均排虫數 \\
\hline $\mathrm{KW}-\mathrm{J}$ & 4 & 10938 & 0 & 100.0 & 100.0 & 100.0 & 75.0 & 6.3 \\
\hline $\mathrm{KW}-\mathbf{I}$ & 5 & - $\quad 10390$ & 1060 & 98.5 & 93.1 & 80.0 & 60.0 & 4.5 \\
\hline
\end{tabular}

* 排虫檢查は 7 日間にわたつて行われたが排便の見のがされたものがあるので，實際はこの數字より 高紊と考えられる。

\section{3. 毒性及び局所刺戟性}

KW-IIに就てマウス經胃投與の毒性を前報2)と同條件で檢した結果，van der Waerden- 法で LD50=12.2士

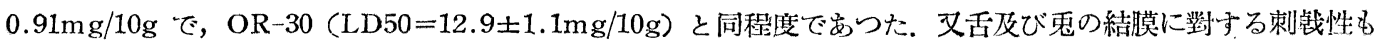
OR-20 ग至 OR-30 と區別できない程度であつた.

\section{KW-I と KW-IIの Diazo- 反應及びクロール含量に就て}

兩憸體の50\%アルコール溶夜を用い黑田の Trim 改變法8) でDiazo-反雔による濃度一吸光度怔線をもとめたと ころ，O.C. R. No.5'に此してかなり高いことが判つた. 同じ方法で O. C. R. に種々の比率に O.R.を配 合したもの（OR-10〜OR-90）との關係を第1圖に示した，佾この圖に既報の有効結晶 O. C. R. No.1，同 No.6 及び Resorcinol の位置をも參考のため示してもる.

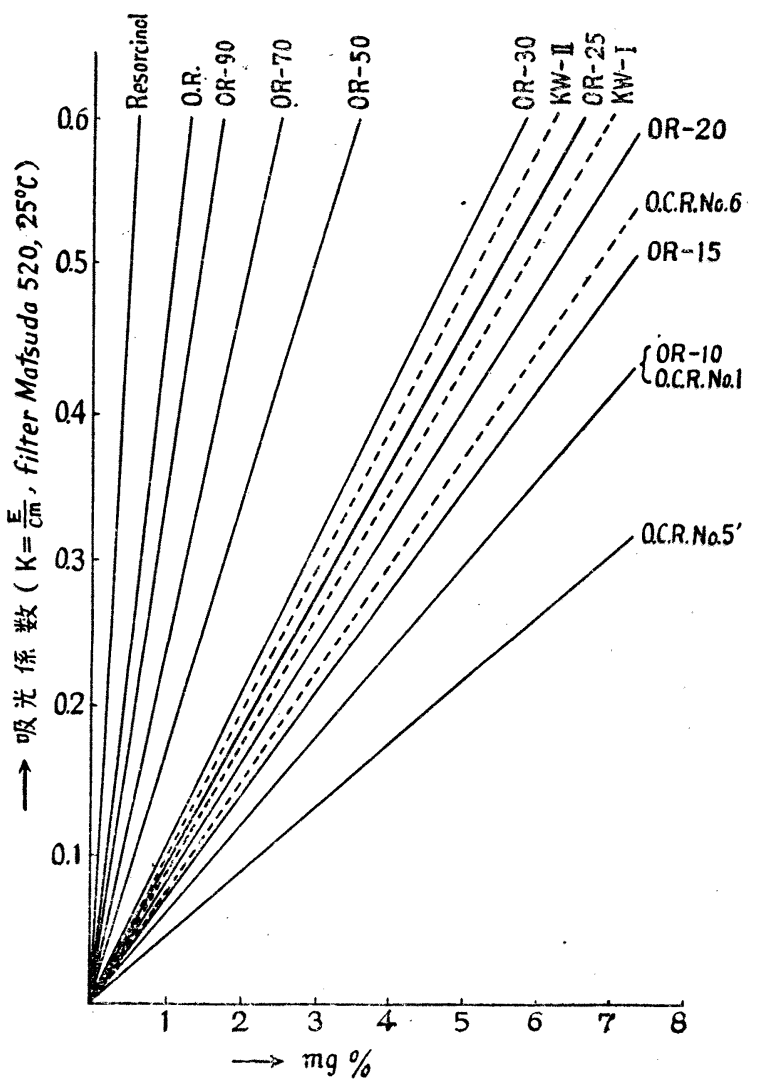

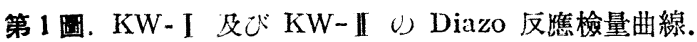

以上の實驗成綪よりみて $\mathrm{KW}-\mathrm{I}$ 及び $\mathrm{KW}$ - II 兩檢體の生物作用は O. C. R. 中に

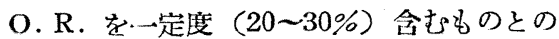
閒に區別し難い類似性が認女以れ, 又Diazo反焦の吸光係數の位置もこれを裹書きしてい る.この反隹に於ける檢量其線の位置を插間 法で求めてみると第 3 表右端闌の值をえた。

そこでクロール含量を實測したところ何れ も純 O. C. R. に比べてずつと少いことが確 定した。この測定值から純 O.C.R.の計算 值を求め爾餘の成分をす心゙て O. R. と假定 した場合の推定值を算出したところ第 3 㳖の よ5で，O.R. 推定値が Diazo- 反焦から推 定した值に沂似していることが制つた。この ことは他の有效 O. C. R. 結晶 No. 1 及び No.6 に就ても檢討してみたが，同樣によく 當てはまることが認められた。

\section{6. 表面張力}

$\mathrm{KW}$ - I 及び KW-I前報2) O.C.R.+O. R.配合物と同じ條件で1：1000䝮蜀夜として 又 $0.1 \%$ 水性鴒和液として表面張力を測つて みると，㲘濁液では $\mathrm{KW}-\mathrm{I} \quad 30.72, \mathrm{KW}-\mathrm{II}$ 30.97 飽和水溶液では何れも29.65 dynes $/ \mathrm{cm}$ の值を示し， OR-30よりや〉低く，O.R. 程度の活性度(前報2)第2 圖參照)を示した。 
第 3 表. 强効力 O.C.R. 結晶のクロール会量と O.C.R. 計算量望びにクロール 不含の成分をすべて O. R・と假定した場合の O. R. 計算量及び

Diazo一反應-吸光度曲線から概算した O.R. 含量.

\begin{tabular}{|c|c|c|c|c|c|}
\hline 檢 & 融 點 ${ }^{\circ} \mathrm{C}$ & $\mathrm{Cl}(\%)^{*}$ & $\begin{array}{l}\text { O.C. R. 計算值 } \\
(\%)\end{array}$ & $\begin{array}{c}\text { O. R. 推 定值 } \\
(\%)\end{array}$ & $\begin{array}{l}\text { Diazo- 反應よb } \\
\text { O.R. 推定 }(\%)\end{array}$ \\
\hline KW- I & $43 \sim 50.5$ & 9.85 & 76.18 & 23.82 & 22.7 \\
\hline $\mathrm{KW}-\mathbf{I I}$ & $43 \sim 51$ & 9.55 & 73.86 & 27.14 & 26.8 \\
\hline O. C. R. No. 1 & $49.5 \sim 51.5$ & 11.88 & 91.87 & 8.13 & 10.0 \\
\hline O. C. R. No. 6 & $45.5 \sim 49.5$ & 10.98 & 84.91 & 15.05 & 16.7 \\
\hline
\end{tabular}

* 純 O. C. R. の Cl 含量 : $12.93 \%\left(\mathrm{C}_{14} \mathrm{H}_{21} \mathrm{O}_{2} \mathrm{Cl}+\mathrm{H}_{2} \mathrm{O}=274.629\right)$

(Cl 定量は京大樂學科富田敎室渡邊恭男氏による)

\section{總括並に考察}

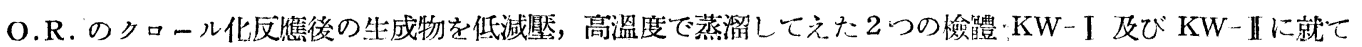
檢萫して次のことが判つた。

1.これらは何れも純 O.C.R.に比心゙融點方゙著しく低く $\left(43 \sim 50.5^{\circ} \mathrm{C}\right)$ ，

2.より表面活性で,

3. Diazo一区焦にはるかに强く呈色する.

4. 何れも純 O.C.R. と異り强力な蜔虫䮠除効果を示与.

5. in vitro 殺蜔虫力子また純O.C.R.より强く, 蜔虫致死時間, 請性, 局所刺戯性等の程度は O.C.R.に O.R.を20〜30\%程度配合したものと近似する。

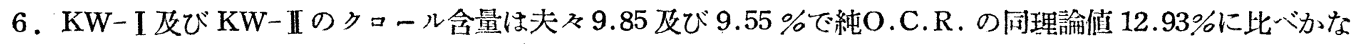
り少い。このクロール不含の成分をすべてO.R.であると假定すると前者は $23.8 \%$ 後者は $27.1 \%$ O.R.を 混入することになる，この推定值は同じ假定の下に Diazo-反雔の吸光係數の佔から計算した O.R. 含量とほ ぶ一致する.

7.この關係は鹪有效結晶 O. C. R. No.1及び No.6 に就てほが同樣に劉められたが，これらは KWに比 ベて O.R. の推定量がや〉少い.

以上の所見からみると $\mathrm{KW}-\mathrm{I}$ 及び $\mathrm{KW}-\mathrm{II}$ 中に含まれている不純物質の性質は O.R.と極めてよく一致1， 又前報2)の貫驗成績に照して，その大部分を O. R. と考えてそれらの生物作用の程度をも矛盾なく證明するこ とができるし，特に满虫効果の優れている理由を理解される。

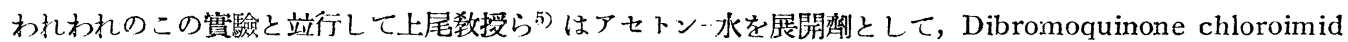
顯色によるベーパークロマトグラフイーによつて Alkylresorcinol-系化合物の同定を行いろることを胃出し， この方法 (アセトンー水 $5: 10$ )によつて，上逝の製品の純度檢定を行つたところ，KW-兩檢體，O.C.R. No.1

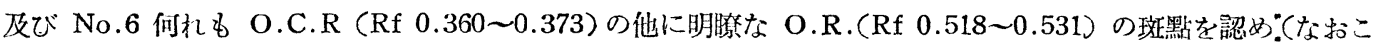
の他に KW-I 及び No.6 に極微量の Resorcinol 及び 6-Chlororesorcinol に相當する斑點を認女ている),

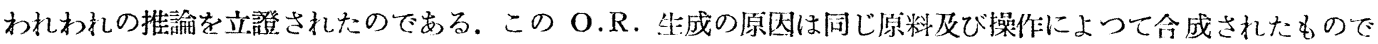
も，高度傎空蒸溜の場合には著明に生成さ扎なかつた點からみて，高溫蒸溜條件下にO.C.R.の膯クロ一ルに よつて生成されることが容易に考えられるが，最近上尾呚授ららは純 O.C.R．の熱分解を試みたとこみやはり O.R.の生成を認めたほか少量の Resorcinol と6-Chlororesorcinolの生成もみられたという。しかし，この 條件でO.R.の分より主として脫解は認めていない，從つて，これらの知見を綜合すれば，O.C.R.は熱分解に クロールし，又一部 Alkyl一側鎻の離断も行われるものと考えられる.

宇野助敎授4は O.C.R.に10〜30\%O.R. を混融後水中に投じ結唱せしめた混合物の X一線粉未第傎にO.C.

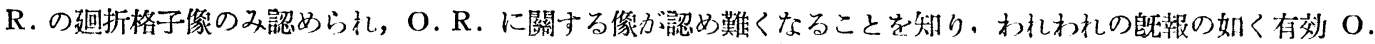

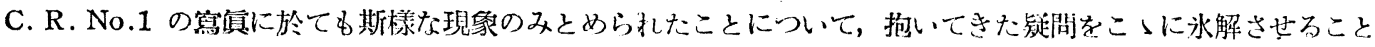


ができた，雨化合物混合の結晶學的な狀態に就ては同氏により，更に詳細に研究されつ১もるが，O.C.R．と

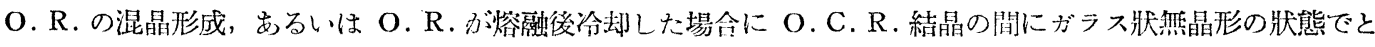
ぶまることなどが考えら扎ている。

たら゙ No.1及び No.6の兩不純 O. C. R. 結晶の O.R. 含是は兩結唱の混入物を O. R. のみと夕る場合,

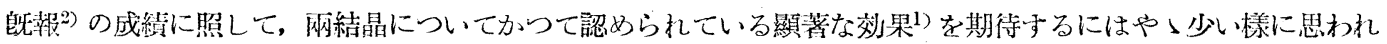
るが，おそらくこれは O.R. 以外に别の活性物質をも含むためであると考えるよりも，前報2の O. C. R. と

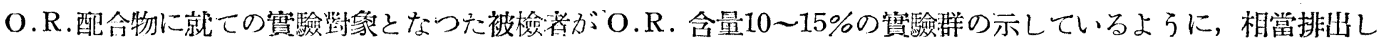
ながらも後卵數が却つて环加しているもの】多い點からみて，畉減率成綪のあがりにくい何らかの條件のもとに

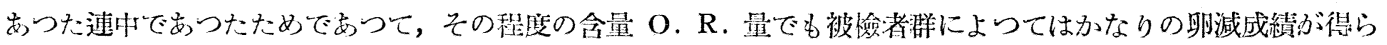
れるのではないかと想像される。

\section{結 論}

刨期につくられた 4-n-Octyl-6-chlororesorcinol が極めて卓效を示したのに临し，その後製造されたもの が著明に低い効果を示したという現象の原因を明らかにするために，われわれは種及1)29910追究を重ねてきたが 今汔の知見をもととし本報の新たにえた事密を加えて考察し，次のように結墖を下すことができる：

效力の强い 4-n-Octyl-6-chlororesorcinol 結唱製品は不純物の一定量を含有している。この不純物は大部 分 4-n-Octylresorcinol であつて， 反倠生成物の蒸溜精製特に減臨度や〉低すき， 溫度上昇のために一部 4-n-Octyl-6-chloresorcinol の分解をおこして止成されたものである. 前者の混入による駱虫効果墰强の機序 は，おそらく融點の低下，界面活性の㙫加等の物理化學的性質の變化により，兩物質の蜔虫角皮への附着並びに 唀入率を帞加せしめるによるのではないかと推考される。

〔本諭文の要旨は第25回日本薬理學會（昭和27年 5 月 7 日阿蘇內之牧）に於て口演發表した〕.

本研究に際して，多大の御協力尼頂いた京大藥學科富田眞雄教授，同宇野豊三助教授，阪大樂學科上尾生次郎 教授及びそれぞれ教室員の諸氏ならびに，日本油脂呼究所武井典夫，高橋越民兩氏に對して厚く感謝申し上げる. なほ又, 本研究は文部省科學研究費, 同科學試驗研究費, 及び岡山縣地方奇生虫病豫防對策協議會の研究費に員 うところが多いことを附訅し，謝意を表する。

\section{引用書目}

1) Yamasaki, H. Mannami, C., and Mayeda, H.: Jap. J. Pharmacol. 1, 63 (1951).

2）山崎英正，万波忠三郎，高岡健男：日本樂理學䆶誌 49, 124 (1953).

3）山崎英正，万波忠三郎：蚼虫驅除劑り綜合研究 (西班) 8，23 (1951).

4) 宇野豊三: 未晸表 (私信).

5）上,尾生次郎, 矢島治明 : 菜學雜誌 73, 371, 376, (1953).

6）山崎䇦正，万波忠三郎：蜔虫驅除劑の綜合研究 (西班) 8，31，(1951).

7) 万波忠三郎：日本樂理學雜誌 48, 172, (1952).

8）黑田章夫: 醫學と生物學 20，195，(1951).

9）万波忠三郎：岡山醫學會雜誌 64, (6) 1271，(1952).

10）万波忠三郎：日本樂理學椎誌 48，159，(1952). 
14. OMIY A, Teruo. Department of Pharmacology, Faculty of Medicine, Kyoto University, Kyoto Studies on the synthetic anticonvulsanis (2) Pharmacological properties of phenyl-glucosides (pp. 119 123) Tables 4

The muscle-relaxing and anticonvulsant properties of $o$-tolyl- $\alpha$-glucoside (1), $o$-tolyl- $\beta$-glucoside (2), guaiacol$\alpha$-glucoside (3) and guaiacol- $\beta$-glucoside (4) have been comparatively studied with the same method as in the previous report (see No. 13 of this Breviaria). Result: All of these compounds possessed no anticonvulsant effect on the covulsions induced by strychnine, picrotoxin and metrazol, except that (1) and (3) revealed only a weaker antagonistic effect against the metrazol action than Myanesin or Hustosil.

\section{Author}

15. YAMASAKI, Hidemasa, MANNAMI, Chuzaburo and TAKAOKA, Tateo. Department of Pharmacology, Okayama Uninersity Medical School Studies on the combined actions of alkylresorcinols as an anthelmintic. III. Combination of 4-noctyl-6-chlororesorcinol and 4-n-octylresorcinol (pp. 124 132) Graphs 2 Tables 9

On the combination of $4-n$-octyl- 6 chlororesorcinol (O.C.R.) and 4- $\boldsymbol{n}$-octylresorcinol (O.R.), marked potentiation was observed as to the ascaricidal power in vitro $(1: 1000)$ as well as to the clinical anthelmintic efficacy. The most efficient ratio of the mixture was 70 parts of O.C.R. to 30 parts of O.R. (equivalent to O.C.R. ca. $2 \mathrm{~mol}$ : O.R. ca. 1 mol.), and its efficacy was obviously more excellent than hexylresorcinol. As to the oral toxicity to mice and the irritant action to the mucous membrane (on the conjunctiva of rabbits and human tongues), this mixture lay between O.R. and O.C.R., and was far weaker than hexylresorcinol. A $0.2 \mathrm{~g}$ per $\mathrm{kg}$ dose was almost harmless to the dog's gastric mucosa. Possible relationship between the potentiation of the ascaricidal property and some physical changes observed such as a lowering of interfacial tension of solution and a fall of melting point of the mixtures was discussed.

Author

16. YAMASAKI, Hidemasa, MAN. NAMI, Chuzaburo and TAKAOKA, Tateo. Department of Pharmacology, Okayama University Medical School On the substance increasing anthelmintic efficacy, produced in the synthesis of 4-n-octyl-6-chlororesorcinol (pp. 133-137) Graphs 1 Tables 3

Two samples obtained by distillation of the chlorinated product of 4-n-octylresorcinol (O.R.) under the higher temperature with lower reduced pressure than is ordinarily used were both proved to be superior in the anthelmintic efficacy against ascaris in man than pure 4- $n$-ectyl6-chlororesorcinol (O.C.R.). These samples were (1) lower in «elting point, (2) more distinctly colored by the diazo-reaction, (3) stronger in interfacial activity of the solution, (4) more efficacious in ascaricidal action in vitro, (5) slightly more toxic and irritant and (6) contained less chlorine than pure crystal of O.C.R.. If we assume that all this chlorine depends upon O.C.R., then these samples must contain 23.8 and $27 \%$ impurities which 
have no chlorine respectively. Mixtures of O.C.R. and O.R. have excellent anthelmintic efficacy, when percentage of the latter lies between 20 and 30 (refer to preceding report), besides having biological and physico-chemical properties which are almost similar, in both quality and quantity, to the samples above mentioned. Moreover, a fairly large amount of O.R. together with traces of resorcinol and 6-chlororesorcinol besides O.C.R. was identified in these samples by a paper chromatographic method, and it was proved that these impurities could be produced by thermal decomposition of O.C.R.. Occasional differences in efficacy of O.C.R. preparations in manufactural lots may be explained in most part to be caused by the concomitant of O.R..

Author

17. ToKITA, Kikuji, IWASAKI, Shige and YUI, Fusae. Department of Pharmacology, Toho University Medical College, Tokyo On the opening motion of mouth and vomiting of frogs after the digitalis preparations and on their mechanisms (pp. 138-142) Tables 3

The frog's lethal doses in the four- hour-method and the doses to open the mouth or to cause vomiting in frogs were given with the digitalis preparations as in the table below. It has been assumed from these results that digicorin, digoxin and digitalis leaves were more rapidly detoxicated than the others. The opening motion of mouth began within several minutes after aglycones injection, while it required more than thirty minutes with the other preparations. The maximal patterns of this motion were reached within one or two hours after the administration, whereby it was even seen a few of frogs drawing their stomachs out of their mouths. The frogs, decerebrated or centrally anesthetized, opened their mouths by the digitalis adminstration, while the frogs, middle-brain or medulla removed, spinal cord destructed or anesthetized with phenobarbital, showed no reaction as such. The frogs, cardiac nerves of which had been cut, opened their mouths by the intravenous injection of digitalis preparations. The hepatectomized or gastroectomized frogs opened their mouths. From the results it is concluded that the digitalis preparations caused vomiting under the influence from the middle-brain reflex pathway, but not from the reflexes passing from the heart, liver or stomach.

\begin{tabular}{l|c|c|c|c|c|c|c}
\hline & Digitoxin & Ouabain & Digicorin & Digoxin & $\begin{array}{c}\text { Digitoxi- } \\
\text { genin }\end{array}$ & $\begin{array}{c}\text { Gitoxi- } \\
\text { genin }\end{array}$ & $\begin{array}{c}\text { Powdered leaves } \\
\text { of digitalis }\end{array}$ \\
\hline $\begin{array}{l}\text { LD in } \\
\text { (mrs. }\end{array}$ & 0.001 & 0.0002 & 0.0515 & 0.0017 & 0.003 & 0.001 & 0.2 \\
\hline $\begin{array}{l}\text { V.D. in } \\
\text { ( } \mathrm{hrs} .\end{array}$ & 0.001 & 0.0002 & 0.0005 & 0.0002 & 0.003 & 0.001 & 0.04 \\
\hline
\end{tabular}

